\title{
的量 New Disease Reports \\ First report of Cucurbit yellow stunting disorder virus infecting cucurbits in Italy
}

\author{
A. Manglli ${ }^{1}$, M. Murenu ${ }^{2}$, M. Sitzia $^{2}$ and L. Tomassoli ${ }^{1 *}$ \\ ${ }^{1}$ Consiglio per la ricerca in agricoltura e l'analisi dell'economia agraria, Centro di Ricerca per la Patologia Vegetale. Via \\ C.G. Bertero, 22 - 00156 Rome, Italy; ${ }^{2}$ Agenzia LAORE Sardegna, Servizio sviluppo delle filiere vegetali, Unità \\ organizzativa sviluppo delle filiere ortofrutticole, Via Caprera 8, 09123 Cagliari, Italy
}

*E-mail: laura.tomassoli@crea.gov.it

Received: 22 Sep 2016. Published: 14 Nov 2016. Keywords: crinivirus, Cucumis melo, Cucurbita pepo, yellowing disease

In June 2016, a survey was conducted in Sardinia, Italy to study the variability of cucurbit viral populations in melon (Cucumis melo var. cantalupo and C. melo var. inodorus) and zucchini (Cucurbita pepo). Two main cucurbit-growing provinces (Cagliari and Oristano) were investigated where, in the last decade, Beet pseudo-yellows virus (BPYV, genus Crinivirus) and Cucurbit aphid-borne yellows virus (CABYV, genus Polerovirus) were found but not Cucurbit yellow stunting disorder virus (CYSDV, genus Crinivirus) despite having been tested for (Tomassoli et al., 2003; Tomassoli \& Meneghini, 2007). Leaf yellowing was widely observed on field-grown melon plants, often associated with thickening, brittleness or cracking and early browning of the lower leaves.

A total of 70 samples from 8 farms (covering an area of approximately $250,000 \mathrm{~m}^{2}$ ) were collected from melon and zucchini plants showing viruslike symptoms. In particular, 25 melon and two zucchini samples were selected for yellowing symptoms (Figs. 1-2) and total RNA was extracted for diagnosis. Molecular tests for CABYV and BPYV were performed as previously described (Tomassoli \& Meneghini, 2007). Fourteen samples were positive for CABYV and two for BPYV. All samples were tested for the presence of CYSDV by single step RT-PCR using a specific primer set that amplifies the complete coat protein $(\mathrm{CP})$ gene (Hourani \& AbouJawdah, 2003). A product of the expected size ( $770 \mathrm{bp})$ was amplified from four winter melon and one zucchini sample, all collected in the province of Cagliari. The DNA fragments were purified and directly sequenced in both directions. The sequence obtained from the five samples showed $100 \%$ identity when aligned. Therefore, the sequence of only one isolate was submitted to GenBank (Accession No. KX768875). BLAST analysis of the nucleotide sequence of this isolate revealed the highest identity (99\%) in the CP gene with sequences published from USA (FJ492808) and Spain (AY242078 and AJ439690). Phylogenetic analysis of the $\mathrm{CP}$ gene sequence showed that the Italian isolate clustered with isolates from different countries in the Mediterranean basin and from the American continent within the "Western" group (Fig. 3) which is phylogenetically distant from the "Eastern" group including isolates from Iran, Saudi Arabia and Sudan (Rubio et al., 2001; Keshevarz et al., 2013). reported in different Mediterranean countries but CYSDV has not been found previously in Italy. The diagnostic results suggest a low incidence of CYSDV since the virus was found in only a few samples and in one surveyed area. For this reason, we presume a recent introduction of the virus and further investigation in Sardinia and other Italian regions is needed.

\section{Acknowledgements}

The survey was supported by an ARIMNet2 project "EMERAMB".

\section{References}

Célix A, López-Sesé A, Almarza N, Gómes-Guillamón ML, RodrìguezCerezo E, 1996. Characterization of Cucurbit yellow stunting disorder virus, a Bemisia tabaci-transmitted closterovirus. Phytopathology 86, 1370-1376.

Hourani H, Abou-Jawdah Y, 2003. Immunodiagnosis of Cucurbit yellow stunting disorder virus using polyclonal antibodies developed against recombinant coat protein. Journal of Plant Pathology 85, 197-204. http://dx.doi.org/10.4454/jpp.v85i3.1031

Keshevarz T, Shams-Bakhsh M, Izadpanah K, Nassaj Hossini SM, 2013. Geographic distribution and phylogenetic analysis of Cucurbit yellow stunting disorder virus in Iran. Acta Virologica 57, 415-420.

http://dx.doi.org/10.4149/av $2013 \quad 04 \quad 415$

Rubio L, Abou-Jawdah Y, Lin HX, Falk BW, 2001. Geographically distant isolates of the crinivirus Cucurbit yellow stunting disorder virus show very low genetic diversity in the coat protein gene. Journal of General Virology 82, 929-933. http://dx.doi.org/10.1099/0022-1317-82-4-929

Tomassoli L, Meneghini M, 2007. First report of Cucurbit aphid-borne yellows virus in Italy. Plant Pathology 56, 720. http://dx.doi.org/10.1111/j.1365-3059.2007.01583.x

Tomassoli L, Lumia V, Siddu GF, Barba M, 2003. Yellowing disease of melon in Sardinia (Italy) caused by Beet pseudo yellows virus. Journal of Plant Pathology 85, 59-61. http://dx.doi.org/10.4454/jpp.v85i1.1010

Since its first identification in 1996 (Celix et al., 1996), CYSDV has been

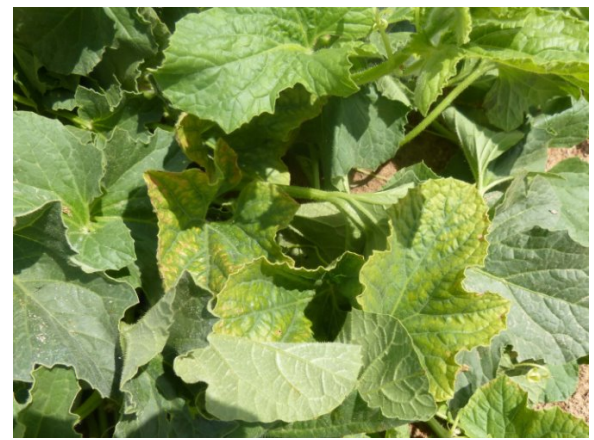

Figure 1

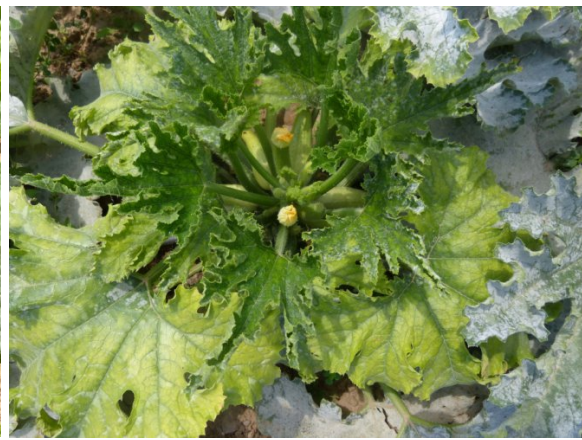

Figure 2

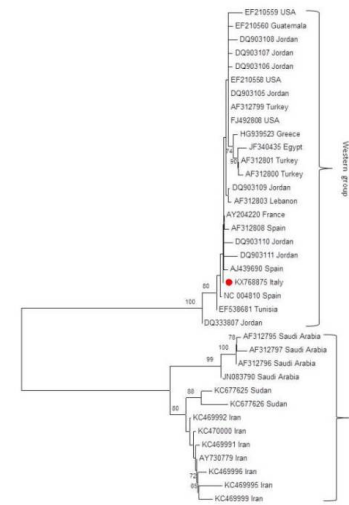

Figure 3

To cite this report: Manglli A, Murenu M, Sitzia M, Tomassoli L, 2016. First report of Cucurbit yellow stunting disorder virus infecting cucurbits in Italy. New Disease Reports 34, 23. http://dx.doi.org/10.5197/j.2044-0588.2016.034.023

(c) 2016 The Authors

This report was published on-line at www.ndrs.org.uk where high quality versions of the figures can be found. 